University of Nebraska - Lincoln

DigitalCommons@University of Nebraska - Lincoln

Agronomy \& Horticulture -- Faculty Publications

Agronomy and Horticulture Department

7-1924

Western Yellow Pine Mistletoe

J. E. Weaver

University of Nebraska-Lincoln

Follow this and additional works at: https://digitalcommons.unl.edu/agronomyfacpub

Part of the Plant Sciences Commons

Weaver, J. E., "Western Yellow Pine Mistletoe" (1924). Agronomy \& Horticulture -- Faculty Publications.

470.

https://digitalcommons.unl.edu/agronomyfacpub/470

This Article is brought to you for free and open access by the Agronomy and Horticulture Department at DigitalCommons@University of Nebraska - Lincoln. It has been accepted for inclusion in Agronomy \& Horticulture -Faculty Publications by an authorized administrator of DigitalCommons@University of Nebraska - Lincoln. 


\section{Western Yellow Pine Mistletoe ${ }^{1}$}

This bulletin gives the results of studies over a period of twelve years on the effect of mistletoe Razoumofskya cryptopoda (Engelm.) Cov. on the growth and seed production of western yellow pine. The intensive part of these studies was carried on near the San Francisco mountains in northern Arizona. "The parasite is the most widely distributed and one of the most serious enemies of the western yellow pine." On southern slopes and near the lower limit of the distribution of the pine, areas occur where 75 to 90 per cent of all trees above six inches in diameter are infected.

The effects of the mistletoe on the bole of the tree are to retard the growth both in height and diameter. Witches brooms and increased thickness of limbs are more common on the infected trees than on the healthy ones. When infection occurs early in the life of trees, burls are frequently formed. The large amount of reserve food of the infected stems, their soft spongy nature, and their thicker inner bark attract porcupines and squirrels. Other effects of mistletoe infection are the production of a flow of resin, and shorter and more yellowish leaves. The life of the tree is shortened, small amounts of seed are produced by infected trees during generally heavy seed

${ }^{3}$ Korstian, Clarence F., and W. H. Long, The Western Yellow Pine Mistletoe: Fffect on Growth and Suggestions for Control. U. S. Department of Agriculture Bul. II 12. pp. 35. Dec. 21, 1922. 
years, and at other times practically none, also the seed is of poorer quality. The merchantability of the timber is reduced both by an increase in the number of knots and by a weakening of the lumber.

The authors state that the most practical method of controlling mistletoe is to remove infected pines while cutting operations are in progress.

The bulletin presents a large amount of carefully collected data in a very clear manner, and fully demonstrates the seriousness of mistletoe infection in a region where forest productivity is retarded by numerous other unfavorable factors.

University of Nebraska.

J. E. Weaver. 